\title{
Hydrogen and syngas production from gasification of lignocellulosic biomass in supercritical water media
}

\author{
Farid Safari $^{1} \cdot$ Ahmad Tavasoli $^{1} \cdot{\text { Abtin } \text { Ataei }^{1} \cdot \text { Jun-Ki Choi }^{2}}^{2}$
}

Received: 4 February 2015/Accepted: 18 March 2015/Published online: 24 March 2015

(C) The Author(s) 2015. This article is published with open access at Springerlink.com

\begin{abstract}
Purpose Novel biomass-processing technologies have been recently used for conversion of organic wastes into valuable biofuels like bio-hydrogen. Agricultural wastes are available and renewable energy resources to supply energy demand of the future. The purpose of this study is to investigate the production of hydrogen-rich syngas from wheat straw, walnut shell, and almond shell.

Methods Supercritical water gasification is a promising technology to convert biomass into useful fuels. Non-catalytic conversion of wheat straw, walnut shell, and almond shell into the hydrogen-rich gas in supercritical water media was performed using homemade batch microreactor system. Results Hydrogen gas yields of 6.52, 4.26 and $4.1 \mathrm{mmol}$ per 1 gram of wheat straw, walnut shell, and almond shell were observed, respectively. In addition, hydrogen and carbon gasification efficiencies equal to 42.6 and $46.9 \%$ were calculated from gaseous products and elemental analysis of wheat straw, which were higher than other feedstocks' gasification efficiencies.

Conclusion Wheat straw had the highest and walnut shell had the lowest total gas and hydrogen gas yields. Taking into account the structural analysis, it was recognized that feedstocks with higher cellulose and hemicellulose and lower lignin contents were better gasified due to their easier hydrolysis and higher solubility in water.
\end{abstract}

Abtin Ataei

a.ataei@srbiau.ac.ir

1 Department of Energy Engineering, Science and Research Branch, Islamic Azad University, Tehran, Iran

2 Department of Mechanical and Aerospace Engineering, Renewable and Clean Energy, University of Dayton, Dayton, $\mathrm{OH}$, USA
Keywords Biomass - Hydrogen production · Gasification - Supercritical water media

\section{Introduction}

Sustainable development in the context of energy is one of the most important road maps for scientists and engineers in recent years. Using renewable energy resources, maximizing energy efficiency and improving energy conservation with novel methods are the strategies for achieving this aim. Research and development in methods of obtaining power from energy resources with less environmental effects and higher efficiencies would be a great leap forward in this way. Biomass is an available and renewable resource that easily can be obtained from nature. Wasting this resource results in harmful environmental effects and causes many problems, while it can be converted into useful products such as hydrogen by different conversional technologies. Conversion of biomass into these products is helping us to supply the energy demand of the future in a sustainable way. Many scientists regard hydrogen as a key energy carrier of the future. The amount of energy released during hydrogen combustion is higher than any other fossil fuels on a mass basis, with a lower heating value (LHV) 2.4, 2.8 and 4 times higher than that of methane, gasoline and coal, respectively. Generally, we have two main methods for hydrogen production from biomass. Thermochemical method, which is divided into three types of processes (pyrolysis, gasification and SCWG) and biological methods (Hepbasli et al. 2009).

In this study, we perform supercritical water gasification that is one of the most promising methods for thermochemical conversion of biomass into hydrogen-rich gas. This technology has many advantages compared with other 
thermochemical conversions. In this method, wet biomass can be converted into the hydrogen-rich syngas at lower temperatures with higher efficiencies due to the high dispersion and effective heat transfer of water in its supercritical condition $\left(374^{\circ} \mathrm{C}, 22.1 \mathrm{MPa}\right)$ (Saxena 2008). Water in SCWG has a twofold role as reaction medium and reactant. The unique solvent properties allow supercritical water to solve the major part of biomass and reform it through a homogeneous mixture. Water-gas shift (producing $\mathrm{H}_{2}$ and $\mathrm{CO}_{2}$ from $\mathrm{CO}$ and $\mathrm{H}_{2} \mathrm{O}$ ) and methanation (producing $\mathrm{CH}_{4}$ and $\mathrm{H}_{2} \mathrm{O}$ from $\mathrm{CO}$ and $\mathrm{H}_{2}$ ) reactions occur with biomass reforming in supercritical water, simultaneously (Calzavara et al. 2005).

Modell et al. (1978) reported the effect of temperature and concentration on the gasification of glucose and maple sawdust in water in the vicinity of its critical state. No solid residue or char was produced. Hydrogen gaseous yield up to $18 \%$ was observed. After that, research and development on this method increased significantly. Guo et al. (2007), concluded that carbohydrates (i.e. cellulose and hemicelluloses) gasified much easier than xylen and lignin, and lignin was the most difficult to gasify. In addition, it was realized that lignin can interact with cellulose and change both the gas yield and product gas composition. Other researchers expressed that, in SCW gasification of real biomass feedstock, char/coke may originate from nondecomposed biomass by a solid-solid conversion; and coke formation in biomass gasification process due to the presence of lignin, not only depends on the lignin amount but also strongly depends on the structure of lignin and interactions between other components in the real biomass (Yanik et al. 2007). In the recent years, Tavasoli et al. (Barati et al. 2014) have studied the gasification of sugarcane bagasse in supercritical water condition. Hydrogen yield up to $37 \%$ was observed in tubular batch microreactor, which was for the gasification in the temperature of $400{ }^{\circ} \mathrm{C}$, with biomass loading of $0.05 \mathrm{~g}$ and water loading of $4 \mathrm{~g}$ in reaction time of $15 \mathrm{~min}$. It was also shown that hydrogen yield was increased with the increment of reactor's temperature while it was decreased with the increment of feed concentration.

In this article, we investigate the gasification of wheat straw, walnut shell and almond shell in supercritical water media with tubular batch rector, which is designed for the efficient reacting condition, considering the latest experiments and research literature.

\section{Materials and methods}

\section{Materials}

The biomass particles used for the experiments were obtained from gardens and agriculture farms around
Sanandaj, located in Kurdistan province, Iran. They were dried under atmospheric conditions for $48 \mathrm{~h}$, and ground to particle sizes $<150$ micrometer in diameter. The elemental compositions of the whole biomass samples were analyzed in a CHNS analyzer.

\section{Reaction setup and experimental outline}

A batch microreactor made of 316 stainless steel tube with total volume of $23 \mathrm{~mL}$ has been used in this study (Fig. 1a). Variation of the reactor's pressure with time is shown in Fig. 1b. Feedstocks were mixed with a certain amount of deionized water and injected into the reactor using a syringe. The reactor was plunged in a molten salt bath that contained a mixture of potassium nitrate, sodium nitrate, and sodium nitrite. The molten salt bath temperature was controlled using an electrical heater and a PID temperature controller. Temperature and pressure were measured using a K-type thermocouple and a pressure gauge. Figure 1b, shows the typical changes in reactor pressure. After a given reaction

(a)
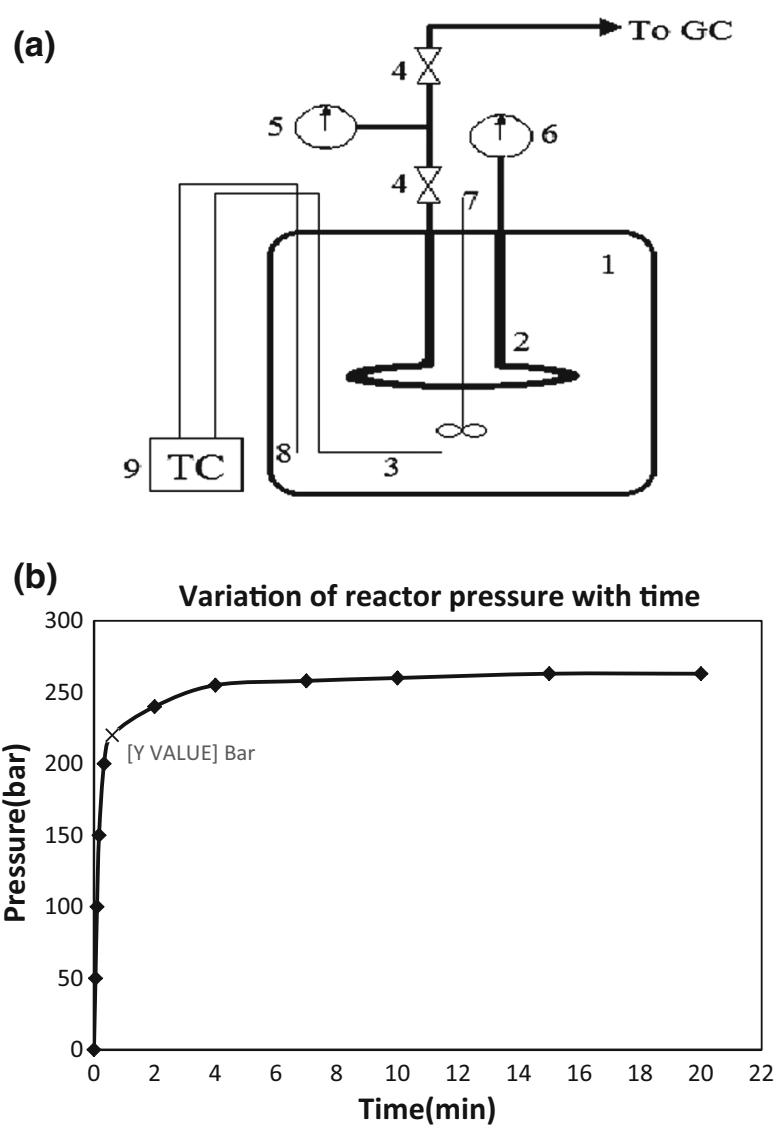

Fig. 1 a Scheme of the homemade tube batch microreactor: 1 molten salt bath 2 batch tube reactor, 3 electrical heater, 4 high-pressure valve, 5 low-pressure gauge 6 high-pressure gauge, 7 mixer 8 k-type thermocouple, 9 temperature controller. b A typical variation of reactor's pressure with time $\left(T 440{ }^{\circ} \mathrm{C}\right.$, wheat $\mathrm{L} 0.05 \mathrm{~g}$, water $\mathrm{L} 5 \mathrm{~g}$ ) 
time, the reactor was taken out of the molten salt bath and plunged in a water bath for rapid cooling to room temperature. All experiments were performed three times and the data reported here are the averages of repetitive runs.

At the end of each experiment, reactor free volume, final pressure and temperature were used to calculate the gas yield. The amounts of each product's gases were measured and analyzed using gas chromatographs (Varian 3400 and Teyfgostar-Compact). The carbon gasification efficiency (CGE), which is the ratio of the amount of carbon in the gaseous products to the amount of carbon in the biomass; and hydrogen gasification efficiency (HGE), which is the ratio of the amount of hydrogen in the gas phase to the amount of hydrogen in the biomass were measured after each experiment. Mathematically, CGE and HGE are defined as (Barati et al. 2014):

$$
\begin{aligned}
\mathrm{CGE}= & \left\{\mathrm{Y}_{\mathrm{CO}}+\mathrm{Y}_{\mathrm{CH}_{4}}+\mathrm{Y}_{\mathrm{CO}_{2}}+2 \mathrm{Y}_{\mathrm{C}_{2} \mathrm{H}_{4}}+2 \mathrm{Y}_{\mathrm{C}_{2} \mathrm{H}_{6}}\right\} \\
& /\{\text { mmol Carbon/g biomass }\} \\
\mathrm{HGE}= & \left\{\mathrm{Y}_{\mathrm{H}_{2}}+2 \mathrm{Y}_{\mathrm{CH}_{4}}+2 \mathrm{Y}_{\mathrm{C}_{2} \mathrm{H}_{4}}+3 \mathrm{Y}_{\mathrm{C}_{2} \mathrm{H}_{6}}\right\} \\
& /\left\{\text { mmol } \mathrm{H}_{2} / \mathrm{g} \text { biomass }\right\}
\end{aligned}
$$

\section{Results and discussion}

\section{Feedstock analysis}

The feedstocks used in this study are lingo-cellulosic biomass. A lingo-cellulosic biomass typically has 30-60\% cellulose, 20-40\% hemicellulose and 15-25\% lignin (Nanda et al. 2013). The CHNS and structural analyses of the biomasses are given in Table 1. As indicated, the $\mathrm{C}$ and $\mathrm{H}$ content in the samples are 48.25 and $6.08 \%$ for wheat straw, 50.2 and $5.67 \%$ for walnut shell, and 49.70 and $5.43 \%$ for almond shell, respectively. The balances are mostly oxygen. In addition, structural analysis shows that the lignin contents in their structure are 19.3, 35 and $38 \%$, respectively, for wheat straw, walnut shell and almond shell.

\section{Reactions}

Because of the lingo-cellulosic structure of biomasses used in this study, it is necessary to study the behavior of the intermediates and their degradation or reformation routes to gases. Prior to understanding the mechanisms, behavior and the breakdown of the complex lingo-cellulosic biomass in supercritical conditions, it is essential to investigate the SCWG of their model compounds such as cellulose, glucose, glycerol, lignin and phenolics. Some of the vital reactions that occur during the gasification of biomass in SCW are as given below (Reddy et al. 2014).

Cellulose hydrolysis : $\mathrm{C}_{6} \mathrm{H}_{10} \mathrm{O}_{5}+\mathrm{nH}_{2} \mathrm{O} \rightarrow \mathrm{nC}_{6} \mathrm{H}_{12} \mathrm{O}_{6}$

Glucose reforming reaction : $\mathrm{C}_{6} \mathrm{H}_{12} \mathrm{O}_{6} \rightarrow 6 \mathrm{CO}+6 \mathrm{H}_{2}$

Lignin hydrolysis :

$$
\left(\mathrm{C}_{10} \mathrm{H}_{10} \mathrm{O}_{3}\right)_{\mathrm{n}}+\mathrm{nH} 2 \mathrm{O} \rightarrow \mathrm{nC}_{10} \mathrm{H}_{12} \mathrm{O}_{4}+\text { Phenolics }
$$

Lignin steam reforming reaction :

$$
\text { Phenolics }+\mathrm{H}_{2} \mathrm{O} \rightarrow \mathrm{CO}+\mathrm{CO}_{2}+\mathrm{H}_{2}
$$

Supercritical water gasification of biomass is a complex process but the overall conversion can be simplified as:

$\mathrm{CH}_{\mathrm{x}} \mathrm{O}_{\mathrm{y}}+(2-\mathrm{y}) \mathrm{H}_{2} \mathrm{O} \rightarrow \mathrm{CO}_{2}+(2-\mathrm{y}+\mathrm{x} / 2) \mathrm{H}_{2}$

Thus $\mathrm{x}$ and $\mathrm{y}$ are the elemental molar ratios of $\mathrm{H} / \mathrm{C}$ and $\mathrm{O} / \mathrm{C}$ in biomass composition. This is an endothermic reaction and shows the reactance effect of water in addition to its solubility, and hydrogen in the water is released by the gasification reaction. In addition to reaction (7) some intermediate reaction can occur in order to complete the gasification process that is mentioned as follows (Rashidi and Tavasoli 2014; Ataei and Azimi 2012).

Steam reforming :

$$
\mathrm{CH}_{\mathrm{x}} \mathrm{O}_{\mathrm{y}}+(1-\mathrm{y}) \mathrm{H}_{2} \mathrm{O} \rightarrow \mathrm{CO}+(1-\mathrm{y}+\mathrm{x} / 2) \mathrm{H}_{2}
$$

Water - gas shift : $\mathrm{CO}+\mathrm{H}_{2} \mathrm{O} \rightarrow \mathrm{CO}_{2}+\mathrm{H}_{2}$

Methanation : $\mathrm{CO}+3 \mathrm{H}_{2} \rightarrow \mathrm{CH}_{4}+\mathrm{H}_{2} \mathrm{O}$

The reforming reactions produce $\mathrm{CO}, \mathrm{CO}_{2}$ and $\mathrm{H}_{2}$, whereas $\mathrm{CH}_{4}$ is produced by methanation and hydrogenation reactions. Water-gas shift reaction (WGS) is another significant reaction of SCWG of biomass. It is obvious that

\begin{tabular}{|c|c|c|c|c|c|c|c|c|}
\hline \multirow[t]{2}{*}{ Feedstock } & \multicolumn{5}{|c|}{ Element analysis (CHNS) (\%wt) } & \multicolumn{3}{|c|}{ Structural analysis (\%wt) } \\
\hline & $\mathrm{S}$ & $\mathrm{N}$ & $\mathrm{H}$ & $\mathrm{C}$ & $\mathrm{O}$ & Lignin & Cellulose & Hemicellulose \\
\hline Wheat straw & 0.22 & 2.11 & 6.08 & 48.25 & 42.80 & 19.30 & 39.80 & 27.30 \\
\hline Walnut shell & 0 & 0.84 & 5.67 & 50.2 & 42.64 & 38 & 36 & 25.43 \\
\hline Almond shell & 0.06 & 1.10 & 5.43 & 49.70 & 41.60 & 35 & 30.70 & 32.60 \\
\hline
\end{tabular}
water-gas shift should be accelerated and methanation should be avoided when hydrogen-rich gas is required (Reddy et al. 2014).
Table 1 Elemental and structural analysis of different feedstocks 


\section{Product analysis}

Total gas yield and its composition is presented in Fig. 2, for the determined condition. The carbon and hydrogen gasification efficiency was also calculated and presented in Fig. 3. As shown, wheat straw has the highest hydrogen yield with $6.52 \mathrm{~mol} / \mathrm{g}$. Moreover, wheat straw has the highest hydrogen and carbon gasification efficiencies equal to 42.6 and $46.9 \%$, respectively. The total gas yields can

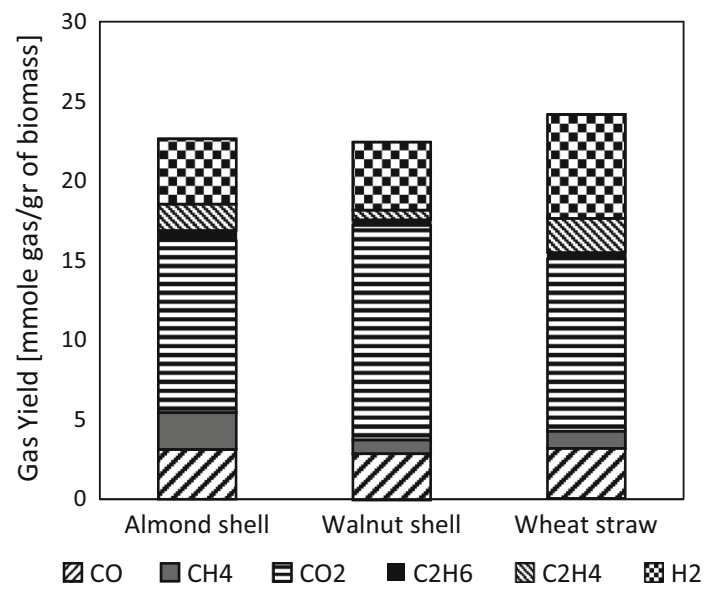

Fig. 2 Gasification yields for different feedstocks $\left(T 440{ }^{\circ} \mathrm{C}\right.$, biomass loading: $0.05 \mathrm{~g}$, water loading: $5 \mathrm{~g}$ )

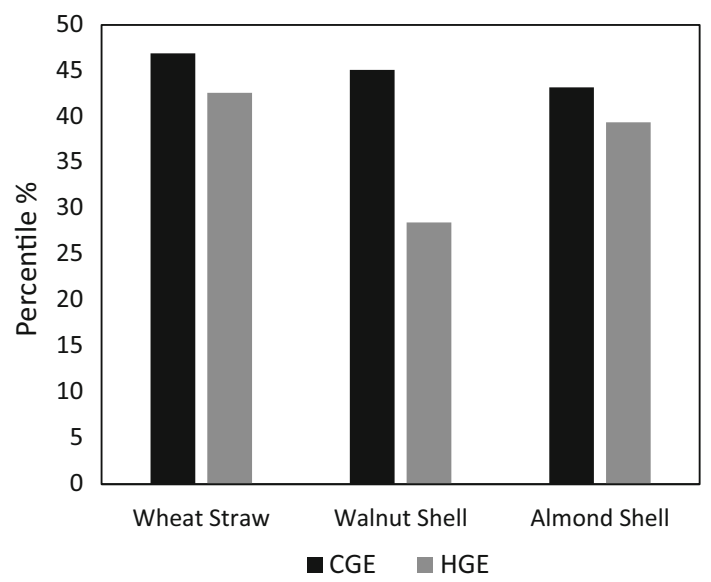

Fig. 3 Hydrogen and carbon gasification efficiencies of feedstocks (T $440{ }^{\circ} \mathrm{C}$, biomass loading: $0.05 \mathrm{~g}$, water loading: $5 \mathrm{~g}$ ) show that the structure of walnut shell with more lignin has the lowest total gas yield equal to $22.4 \mathrm{~mol} / \mathrm{g}$ since the wheat straw has the highest yield with 24.2 mol gas per gram of it. This is because of the higher resistance of lignin during hydrolysis that can postpone the complete gasification. Lignin in the biomass acts as a binding agent that holds cellulose and hemicellulose together, providing firmness to the lingo-cellulosic network. This makes the biomass resistant to various chemicals and enzymes $(\mathrm{Ku}-$ mar et al. 2009). The presence of lignin in biomass makes it difficult to obtain cellulose and hemicellulose to produce fermentable sugars (Reddy et al. 2014). The results in Table 2 show the final composition of the syngas for different feedstocks. SCW gasification process is the result of combination of the series of complex and competing reactions mentioned earlier in this article.

In this study, in addition to comparison between different feedstocks in terms of total gas yield and hydrogen yield per mass unit, the relationship between biomass structure and gas yields was also investigated. There is no certain proved mechanism for supercritical water gasification. However, results indicate that the total gasification yields are approximately related to the total amount of cellulose and hemicellulose in the structure of biomass. This is because of higher solubility of cellulose and hemicellulose compared with lignin, but lignin structure can be dissolved in water in higher temperatures and resident times and specific conditions. Here, wheat straw with higher hydrogen content in its elemental analysis showed the highest hydrogen yield. Therefore, it can be said that the hydrogen content in CHNS analysis has an almost direct relationship with hydrogen gas yield.

\section{Conclusion}

The gasification of wheat straw, walnut shell and almond shell in supercritical water media was studied using a batch microreactor with volume $23 \mathrm{~mL}$. These experiments were performed at the temperature $440{ }^{\circ} \mathrm{C}, 0.05 \mathrm{~g}$ biomass loading, and $0.05 \mathrm{~g}$ water loading with resident time of $15 \mathrm{~min}$. The hydrogen gas yield of $6.52 \mathrm{~mol}$ per gram and the ratio of $27 \%$ in total gas were observed for wheat straw as the highest hydrogen yield among experimented
Table 2 Gas composition and gasification efficiencies for supercritical water gasification of different feedstocks. (T: $440{ }^{\circ} \mathrm{C}$, biomass loading: $0.05 \mathrm{~g}$, water loading: $5 \mathrm{~g}$ )

\begin{tabular}{|c|c|c|c|c|c|c|c|c|}
\hline \multirow[t]{2}{*}{ Biomass } & \multicolumn{2}{|c|}{ Gasification efficiency (\%) } & \multicolumn{6}{|c|}{ Gas composition (mmol gas/g of biomass) } \\
\hline & HGE & CGE & $\mathrm{CO}$ & $\mathrm{CH}_{4}$ & $\mathrm{CO}_{2}$ & $\mathrm{C}_{2} \mathrm{H}_{6}$ & $\mathrm{C}_{2} \mathrm{H}_{4}$ & $\mathrm{H}_{2}$ \\
\hline Wheat straw & 42.6 & 46.9 & 3.1933 & 1.078 & 10.82 & 0.41 & 2.15 & 6.52 \\
\hline Walnut shell & 28.5 & 45.1 & 2.86 & 0.883 & 13.47 & 0.362 & 0.607 & 4.26 \\
\hline Almond shell & 39.4 & 43.2 & 3.12 & 2.31 & 10.80 & 0.647 & 1.65 & 4.1 \\
\hline
\end{tabular}


feedstocks. Results indicated that wheat straw, walnut shell, and almond shell had the highest hydrogen yield, respectively, and wheat straw, almond shell, and walnut shell showed the highest hydrogen gasification efficiency, respectively. It was also recognized that cellulose and hemicellulose were better gasified than lignin because of their easier hydrolysis and higher solubility in water.

Open Access This article is distributed under the terms of the Creative Commons Attribution License which permits any use, distribution, and reproduction in any medium, provided the original author(s) and the source are credited.

\section{References}

Ataei A, Azimi A, Behboodi Kalhori S, Foroughi Abari S, Radnezhad $\mathrm{H}$ (2012) Performance analysis of a co-gasifier for organic waste in agriculture. Int J Recycl Org Waste Agric 1:6

Barati M, Babatabar M, Tavasoli A, Dalai AK, Das U (2014) Hydrogen production via supercritical water gasification of bagasse using unpromoted and zinc promoted $\mathrm{Ru} / \gamma-\mathrm{Al} 2 \mathrm{O} 3$ nanocatalysts. Fuel Proc Tech 123:140-148

Calzavara Y, Dubien CJ, Boissonnet G, Sarrade S (2005) Evaluation of biomass gasification in supercritical water process for hydrogen production. Energy Conv Manage 46:615-631
Guo LJ, Lu YJ, Zhang XM, Ji CM, Guan Y, Pei AX (2007) Hydrogen production by biomass gasification in supercritical water: a systematic experimental and analytical study. Catal Today 129:275-286

Hepbasli A, Kalinci Y, Dincer I (2009) Biomass-based hydrogen production: a review and analysis. Int $\mathrm{J}$ Hydrog Energy 34:8799-8817

Kumar P, Barrett DM, Delwiche MJ, Stroeve P (2009) Methods for pretreatment of lignocellulosic biomass for efficient hydrolysis and biofuel production. Ind Eng Chem Res 48:3713-3729

Modell M, Reid RC, Amin S (1978) Gasification Process, US Patent 4,113,446, September 1978

Nanda S, Mohanty P, Pant KK, Naik S, Kozinski JA, Dalai AK (2013) Characterization of North American lignocellulosic biomass and biochars in terms of their candidacy for alternate renewable fuels. Bio Energ Res 6:663-677

Rashidi M, Tavasoli A (2014) Hydrogen Rich gas production via noncatalytic gasification of sugarcane bagasse in supercritical water media. Pet Coal 56(3):324-331

Reddy Sivamohan N, Nanda Sonil, Dalai Ajay K, Kozinski Janusz A (2014) Supercritical water gasification of biomass for hydrogen production. Int J Hydrogen Energy 39:6912-6926

Saxena RC, Seal D, Kumar S, Goyal HB (2008) Thermo-chemical routes for hydrogen rich gas from biomass: a review. Renew Sustain Energy Rev 12:1909-1927

Yanik J, Ebale S, Kruse A, Saglam M, Yüksel M (2007) Biomass gasification in supercritical water: part 1. Effect of the nature of biomass. Fuel 86:2410-2415 